\title{
The Effect of Climate Change on Controlled Drainage Effectiveness in the Context of Groundwater Dynamics, Surface, and Drainage Outflows. Central-Western Poland Case Study
}

\author{
Mariusz Sojka ${ }^{1}$, Michał Kozłowski ${ }^{2}$, Barbara Kęsicka ${ }^{1}$, Rafał Wróżyński ${ }^{1}{ }^{\circledR}$, Rafał Stasik ${ }^{1}{ }^{1}$, \\ Michał Napierała ${ }^{1}\left(\mathbb{D}\right.$, Joanna Jaskuła ${ }^{1, *(\mathbb{D})}$ and Daniel Liberacki ${ }^{1}$ \\ 1 Institute of Land Improvement, Environmental Development and Geodesy, Faculty of Environmental \\ Engineering and Spatial Management, Poznań University of Life Sciences, Piątkowska 94, 60-649 Poznań, \\ Poland; mariusz.sojka@up.poznan.pl (M.S.); barbara.kesicka@up.poznan.pl (B.K.); \\ rafal.wrozynski@up.poznan.pl (R.W.); rafal.stasik@up.poznan.pl (R.S.); \\ michal.napierala@up.poznan.pl (M.N.); daniel.liberacki@up.poznan.pl (D.L.) \\ 2 Department of Soil Science and Land Reclamation, Faculty of Environmental Engineering and Spatial \\ Management, Poznań University of Life Sciences, Piątkowska 94, 60-649 Poznań, Poland; \\ michal.kozlowski@up.poznan.pl \\ * Correspondence: joanna.jaskula@up.poznan.pl
}

Received: 24 March 2020; Accepted: 24 April 2020; Published: 28 April 2020

\begin{abstract}
Control drainage (CD) is a common practice implemented to control the water balance of drainage fields by increasing the amount of water retained in soil. Worldwide studies suggest that climate change can reduce the effectiveness of CD solutions, but no study of CD effects has been carried out in Polish conditions yet. In this study, the DRAINMOD (Wayne Skaggs, North Carolina State University, Raleigh, USA) computer simulation model was used to predict the effects of CD on the time horizons of 2021-2050 (near future) and 2071-2100 (far future) assuming the Representative Concentration Pathway (RCP) 4.5 emission scenario. The effectiveness of CD solutions is presented for a drainage network with spacing of 7 or $14 \mathrm{~m}$. Additionally, different dates of blocking the outflow from the drainage network (1st and 15th of March and 1st and 15th of April) and different initial groundwater table conditions $(0.4,0.6$, and $0.8 \mathrm{~m})$ were assumed. All simulations for different variants were carried out for the same period, i.e., from 1st of March to 30th of September. The results of climate models indicated that in the area of central-western Poland in the near and far future there will be an increase in air temperatures by 1.02 and $1.97^{\circ} \mathrm{C}$, respectively, and in precipitation by $5.98 \%$ and $10.15 \%$, respectively. In addition, there will be a change in the structure of precipitation, especially with respect to the extension of rain-free periods and an increase in the amount of extreme daily precipitation. The effect of climate change will be a decrease in the mean groundwater table in the fields equipped with drainage systems from 2 to $5 \mathrm{~cm}$. In addition, the number of days on which groundwater table will be above the level of the drainage network will decrease. For the drainage network with spacing of $7 \mathrm{~m}$, the time of the groundwater table above the level of the drainage network will decrease by 5 and 7 days in the near and far future, respectively, while for the drainage network with spacing of $14 \mathrm{~m}$, it will decrease by 4 and 7 days. Climate change will also reduce sub-surface outflow. Subsurface outflows will be smaller than those currently recorded on average by $11 \%$ and $17 \%$ and $12 \%$ and $18 \%$ for $7 \mathrm{~m}$ and $14 \mathrm{~m}$ spacing drainage networks, in the near and far future, respectively. The increase in rainfall intensity in the near and far future will result in a fivefold increase in surface outflow in comparison to the present situation. The simulations show that the greatest effectiveness of CD solutions will be achieved by starting the blocking of outflow from the drainage network on the 1st of March. The implementation of CD solutions since April in the near and far future will allow maintaining the groundwater table at the level presently observed for the conventional network (free drainage-FD).
\end{abstract}


Keywords: agriculture; climate change; drainage water management; control drainage; DRAINMOD

\section{Introduction}

Poland is a country with very limited water resources with practically every year water deficits (defined as reduction of evapotranspiration caused by meteorological drought) mainly in the period of plant growth. Since the 1990s, actions have been taken to store water for agricultural purposes through the construction of reservoirs [1]. These activities allowed storage of water in winter and spring in reservoirs and its use for irrigation in the period of the agricultural drought. Solutions of this type are extremely expensive, first of all because of the high cost of construction of reservoirs and infrastructure for water allocation. Another source of high cost is the allocation of water and the maintenance of reservoirs collecting water for agricultural purposes. Due to the small depths and high nutrient supply, the reservoirs become intensively overgrown, while as a result of the sedimentation, their volume is reduced [2-4]. In addition, reservoirs primarily built for agricultural purposes are also used for recreational, hydropower, fishing, and flood control purposes. Water management of such reservoirs is difficult and most often agricultural purposes play a secondary role. In addition to the construction of reservoirs, due to the occurrence of periodic excess water in spring, a drainage network was developed between the 1950s and 1990s. In Poland, subsurface drainage systems were developed on the surface area of $4.2 \times 10^{6}$ ha, which accounted for about $30 \%$ of arable land. The drainage systems in the world have been constructed on the area of around $193.9 \times 10^{6}$ ha of arable land. However, in 30 countries, the total drained area is more than $1.0 \times 10^{6}$ ha [5].

Increasing attention has been paid to the potential threats that agriculture will have to face in future. In particular, the impact of climate change is highlighted on agricultural production risk. The increase in this risk is related to the increasing occurrence and intensity of agricultural and hydrological drought in response to the increase in evapotranspiration and variability of runoff, at a relatively constant rainfall [6]. The climate changes involve the values of minimal, mean, and maximal temperatures as well as the amounts and seasonal patterns of rainfall. Particularly worth highlighting are the rainfall pattern changes, which will lead to the events of intense short-term rainfalls after long rainfall-free periods. Therefore, the risk of hydrological and agricultural drought is expected to grow [6-8]. On the other hand, there will be loss of water and nutrients for crops and soil degradation due to increase in the surface outflow, erosion, and nutrient runoff [9]. Increasing frequency of periods with too much and too little water will result in farmers facing complex decisions regarding whether they should adapt by investing in an irrigation system, a drainage system, or both, and when [10]. Farmers mainly consider investing in irrigation systems, while drainage systems are not considered as infrastructure to mitigate the effects of climate change on agriculture. Nowadays, during a period of dramatic water resources changes and their uncertainty, there is a need to move from traditional high water demand cropping and irrigation practices to modern systems and technologies [11]. Misra [12] highlighted the need to develop new and improve existing irrigation infrastructure in all vulnerable countries to cope with climate change risks. However, in the case of deep droughts, the use of irrigation systems may bring limited results, because the water abstraction for irrigation will be limited or even impossible due to low stream flows and dry ponds or wells [13]. Moreover, it is necessary to increase the water use efficiency [11]. Raising water productivity is possible through improving water management practices on agricultural lands [14] and joint actions by adopting proven agronomic and water management practices [15]. The main objective of these activities is to minimize loss of water by evaporation from the soil or percolation beyond the depth of the root zone [6]. Water-use efficiency improvement may effectively mitigate water shortages and intensify the resilience of agricultural systems to climate change [16]. Moreover, climate change will require the choice of appropriate crops, improvements in crop cultivars, maintenance of the drainage and irrigation systems, and optimization of water management $[17,18]$. Furthermore, Wolfe et al. [10] indicated the need for improved soil water holding 
capacity and water reservoirs collecting water from drainage systems for use as a water source during dry periods.

Tile drainage systems (TDS) are a potential element of the agriculture adaptation to climate change. TDS are currently relatively poorly used to control drainage and to storage soil water [19]. They are built to drain soils, which are seasonally or perennially wet to allow their agricultural use or increase the efficiency of agricultural production. In traditional TDS, also called free drainage (FD), excess water is drained in an uncontrolled way when the groundwater table exceeds the drainage depth. However, due to the functioning of FD, there are also undesirable effects related to increased nitrogen and phosphorus outflow, which leads to deterioration of surface water quality. Nowadays the challenges of modern agriculture are to improve management practices to increase the efficiency of water use for food production and to reduce water pollution caused by nutrient outflows [14]. Reducing agricultural pollution is essential to improve lake and river water quality [20-24]. Conservation planning in tile-drained plots will require a combination of surface-water best management practices (BMPs) and conservation practices that reduce subsurface agricultural runoff [25]. For this reason, drainage water management (DWM) or controlled drainage (CD) solutions are promoted to control subsurface outflows and to reduce nitrogen and phosphorus loads from FD [26]. CD solutions allow a control of outflow from the drainage network. For this purpose, simple structures installed directly on the drainage network were used. The outlet elevation can be set at a level between the ground surface and the drainage depth. Despite growing interest in CD solutions, the adaptation of existing FD systems is limited. The modernization of FD systems to CD systems is dependent on current design, the age of tile drains or the type of pipelines [27]. The CD solutions are most effective in relatively flat locations $[26,28]$. In such cases, a single control structure affects a relatively large area. Cooke and Verma [26] have pointed out that the CD solution should always be considered when new drainage systems are to be installed or when old systems are to be replaced. The results of a CD solution depend on drainage system design, location, soil, site conditions and the period of adjusting the outlet elevation $[19,29]$. Generally, the CD solution was found to have significant effects on water and nutrient balance in agricultural land [30]. The CD solution enables elevation of the groundwater table and thus reduction of drought stress by storing water in the field [31] and decrease the water use for irrigation. Chartzoulakis and Bertaki [11] have pointed out that the time of irrigation and the amount of water to apply depend on water availability in the soil. The management of drainage outlets enables reduction of drainage volumes as well as nitrogen and phosphorus losses to the environment [32]. Iglesias and Garrote [33] have suggested that improvement of drainage systems on a farm scale could be the best option in terms of water use efficiency, increasing soil retention capacity and decreasing agricultural diffuse pollution.

The climate change will have an impact on agricultural adaptation activities and alter the effectiveness of agricultural mitigation strategies [34,35]. It is also important to understand how agriculture may respond to changes in water supply [36]. Modeling is one of the ways that enable assessment of the impact of climate change on the effectiveness of current and future adaptation [37]. [38]. During the simulation, it is possible to take into account the variability associated with extreme climatic events along with gradual long-term changes [39]. The hydrological model applications have included the impact of climate change on: (1) hydrology, runoff, and nitrogen losses [40], (2) tile flow and nitrogen outflow from tillage and no tillage practices [41], (3) agricultural water demand [42], and (4) the impact of agricultural management practices on nitrogen losses and corn yield in a tile- drained field [30].

The increase in the frequency and intensity of drought occurrence in Europe and, thus, in Poland, means that many countries have to face a major challenge in taking urgent action to limit the future impact on agriculture. It is related to making strategic decisions that are economically justified without a negative impact on the environment. It is pointed out that solutions should also be effective in both the short- and long-term perspective. Therefore, it is important to answer the following questions. How will the drainage systems function in the future? What will the results of CD solutions be? To what extent is it possible to use it to mitigate the effects of water shortages in the short- and long-term 
perspective? The aim of the study is to assess the impact of the implementation of control drainage solutions on the groundwater table, surface runoff, and drainage outflow. To fully understand the potential benefits and limitations of using the drainage network, simulations were carried out assuming the temperature and precipitation changes according to the Representative Concentration Pathway (RCP) 4.5 emission scenario. Simulations were made for two time horizons (2021-2050 and 2071-2100), different weather conditions (dry, normal and wet period), initial groundwater table conditions (initial groundwater table), drainage network parameters (drainage spacing), and CD solution (dates of the beginning of blocking the outflows). Moreover, the results of this study are expected to indicate whether the use of CDs will help to mitigate the effects of climate change on agriculture. Another objective of this study is to achieve good water status by limiting nitrogen outflow from agricultural areas. The need to take such action results from the implementation of the Water Framework Directive and the Nitrates Directive by the EU Member States.

This study was part of a larger research project entitled "Technological innovations and system of monitoring, forecasting and planning of irrigation and drainage for precise water management on the scale of drainage/irrigation system (Acronym-INOMEL)". The project was designed to develop operational water management plans in CD systems based on the results of meteorological and hydrological monitoring and short-term forecasts. The $\mathrm{CD}$ managements plans will take into account the scheduling of fieldwork (sowing, harvesting, etc.) and the crops' water demand.

\section{Materials and Methods}

\subsection{Study Area Description}

The study site is the arable land located in the central-western part of Poland $\left(52^{\circ} 21^{\prime} 38.5^{\prime \prime} \mathrm{N}\right.$, $17^{\circ} 36^{\prime} 34.2^{\prime \prime}$ E) (Figure 1). This area is one of the zones most vulnerable to drought [43], which is associated with the largest losses in crop yields [8]. The average annual air temperature in the analyzed area was $9.1^{\circ} \mathrm{C}$ and the annual precipitation is $542 \mathrm{~mm}$. The research area covers 107 ha. Detailed studies were conducted in the drainage section no. 42 , which has been divided into four subsections 42_1, 42_2, 42_3, and 42_4 (Figure 1).
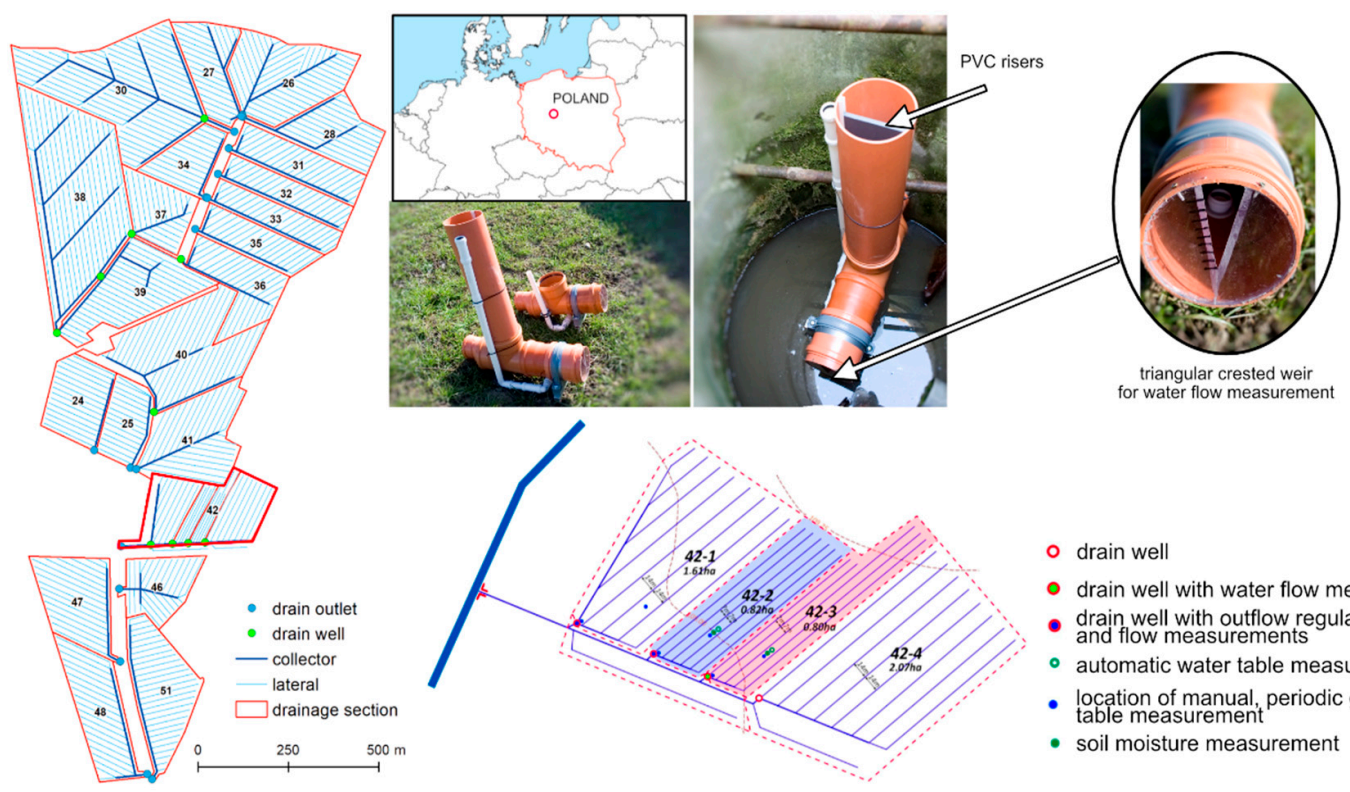

drain well
drain well with water flow measurements
- drain well with outflow regulator
and flow measurements
- automatic water table measurements
- location of manual, periodic ground water
- table measurement
- soil moisture measurement

Figure 1. Study site description.

Each subsection has one outlet with a control well. Periodic measurements of outflows from each subsection were carried out in the years 1988-2003. In 2019, the research restarted and included 
measurements of subsurface outflow. The water table level at each plot was measured by piezometers located between two central lateral drains. A Solinst LTC Levelogger Edge pressure sensor (Solinst Canada Ltd., Georgetown, ON, Canada) was installed in each control well. Measurement rate was set to $1 \mathrm{~h}$ in each sensor.

Moreover, in the subsections 42_2 and 42_3 also measurements of soil moisture at depths 10, 20, $30,40,50,60 \mathrm{~cm}$ were conducted. The volumetric soil water content was measured by means of the frequency domain reflectometry (FDR) technique implemented in WaterScout SM100 soil moisture sensors. The measurements were performed at a once per hour frequency. Subsections $42 \_3$ and $42 \_4$ work in a conventional way, the so-called free drainage (FD), whereas in subsections $42 \_1$ and $42 \_2$ controlled drainage (CD) activities were carried out. At these subsections, simple systems based on the elbow were installed on each well. To regulate outflows, inside of these pipes the modular Poly Vinyl Chloride (PVC) risers were equipped. Additionally, at the end of each control structures the triangular crested weirs for water flow measurement were installed. The outflow logging was based on a pressure level sensor mounted in a white tube (Figure 1).

A general view of the devices controlling groundwater table control and the triangular (V-notch) weir measuring the subsurface outflow were shown in Figure 1. In subsections 42_2 and 42_3, the drainage network has $7 \mathrm{~m}$ spacing, while in sections 42_1 and 42_4 it has $14 \mathrm{~m}$ spacing. The drainage network was made of PVC pipes with a diameter of $0.05 \mathrm{~m}$, which were installed at a depth of $0.90 \mathrm{~m}$ b.s.1. The groundwater table control structures equipped with the V-notch weirs were installed in drainage wells. Previous research [19] has shown the current possibilities of using CD solutions in Poland and their impact on groundwater table dynamics and subsurface outflow. In this paper, the analysis focuses on the potential impact of climate change on the effectiveness of CD solutions in the context groundwater table dynamics and surface and drainage outflows. The data presented in Table 1 were also the input parameters for the DRAINMOD computer simulation model. The study area is slightly heterogeneous in terms of hypsometry; the height of the terrain varies from 107.27 to $109.48 \mathrm{~m}$ a.s.l. Slopes are lower than 0.5\%. The soils were classified as Gleyic Luvisols [44] that developed from glacial till. Both the surface and subsurface soil layers have a sandy loam texture. The argic horizon has higher clay content than the overlying layers.

Table 1. Soil properties at the Ostrowo Szlacheckie site.

\begin{tabular}{|c|c|c|c|c|c|c|c|c|c|c|}
\hline Soil Properties & $42 \_1$ & & $42 \_2$ & & & $42 \_3$ & & & $42 \_4$ & \\
\hline Sand fraction $(\%)$ & 66 & 62 & 66 & 61 & 63 & 66 & 63 & 62 & 66 & 61 \\
\hline Clay fraction $(\%)$ & 11 & 20 & 12 & 20 & 18 & 11 & 19 & 16 & 10 & 21 \\
\hline Silt fraction $(\%)$ & 23 & 18 & 22 & 19 & 19 & 23 & 18 & 22 & 24 & 18 \\
\hline \multicolumn{11}{|c|}{ Soil water retention $\left(\mathrm{cm}^{3} \cdot \mathrm{cm}^{-3}\right)$} \\
\hline Saturated water content & 0.390 & 0.335 & 0.391 & 0.336 & 0.335 & 0.397 & 0.335 & 0.336 & 0.381 & 0.339 \\
\hline Soil water content at field capacity & 0.246 & 0.247 & 0.245 & 0.250 & 0.242 & 0.247 & 0.243 & 0.241 & 0.242 & 0.252 \\
\hline Plant available water & 0.177 & 0.128 & 0.175 & 0.128 & 0.132 & 0.180 & 0.129 & 0.138 & 0.176 & 0.127 \\
\hline
\end{tabular}

\subsection{DRAINMOD Model Description}

DRAINMOD is a field-scale model, which enables the calculation of the water balance components on a daily time step. The calculations are carried out in relation to unit surface area, which is a vertical soil column (Figure 2). Hydrologic variables such as evapotranspiration (ET), surface runoff $(\mathrm{SR})$, infiltration $(\mathrm{I})$, subsurface drainage $(\mathrm{SD})$, surface water storage change $(\Delta S)$, deep seepage 
(DS), and the water-free pore space and air volume $(\Delta \mathrm{Va})$ are predicted by the model. The input data were precipitation $(\mathrm{P})$ and air temperature $(\mathrm{T})$. The DRAINMOD model was developed by Skaggs [45], but its usefulness has been verified many times and presented in numerous scientific publications [32,41,46-48].

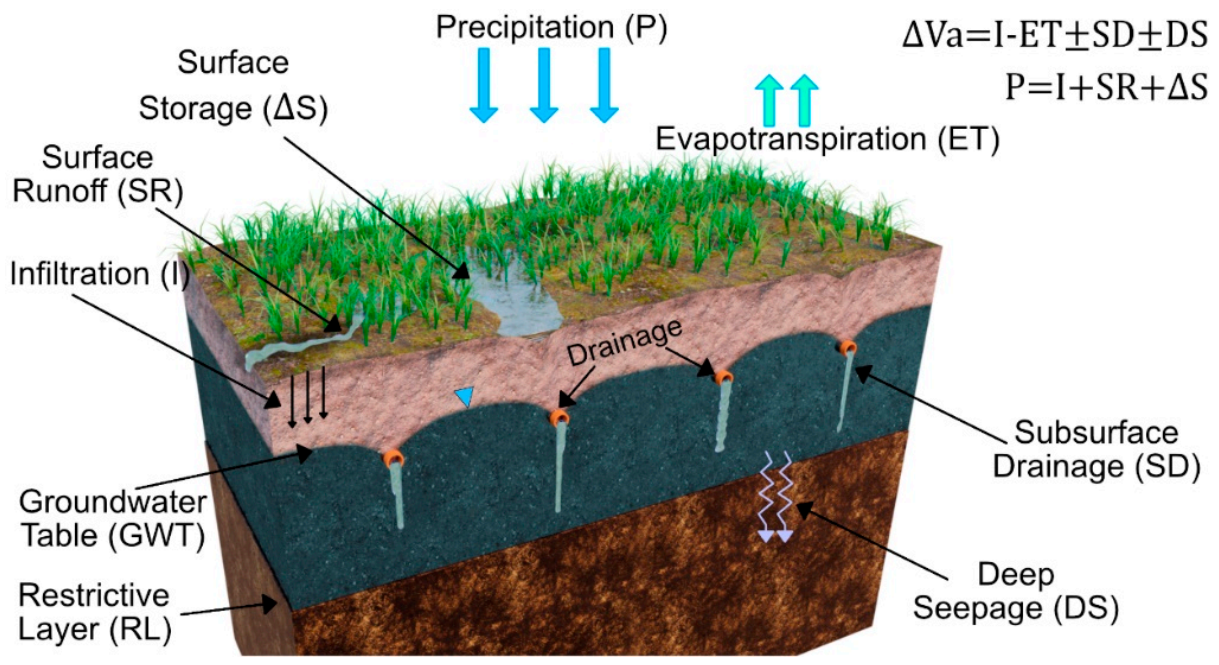

Figure 2. DRAINMOD calculation schema.

\subsection{Model Inputs and Climate Change Impact Manipulation}

The identification of model parameters and the procedure of the model calibration and validation were carried out using the procedure described by Skaggs et al. [45]. Groundwater table measurements from 2000 were used to calibrate the model. The hydraulic conductivity of layer/horizon, especially below the soil depth, the thickness of the restrictive layer, and the hydraulic head at the bottom of the restrictive layer, within reasonable ranges, were adjusted to minimize the difference between the observed and predicted groundwater table depths. After calibration, the model was validated on the basis of groundwater table measurements from 1994 using standard statistical measures, such as the root mean square error (RMSE), coefficient of mass residual (CRM), index of agreement, (d) and model efficiency index (EF) $[49,50]$. These statistics are defined as:

$$
\begin{gathered}
\text { RMSE }=\left(\sum_{i=1}^{n}\left(P_{i}-O_{i}\right)^{2} / n\right)^{1 / 2} \\
C R M=\frac{\left(\sum_{i=1}^{n} P_{i}-\sum_{i=1}^{n} O_{i}\right)}{\sum_{i=1}^{n} O_{i}} \\
d=1-\frac{\sum_{i=1}^{n}\left(P_{i}-O_{i}\right)^{2}}{\sum_{i=1}^{n}\left(\left|O_{i}-O\right|+\left|P_{i}-O\right|\right)^{2}} \\
E F=1-\frac{\sum_{i=1}^{n}\left(O_{i}-O\right)^{2}-\sum_{i=1}^{n}\left(P_{i}-O_{i}\right)^{2}}{\sum_{i=1}^{n}\left(O_{i}-O\right)^{2}}
\end{gathered}
$$


where $n$ is the total number of the observations, $O_{i}$ is the observed value of the $i$ th observation, $P_{i}$ the predicted value of the $i$ th observation, and $O$ the mean of the observed values $(i=1$ to $n)$. The RMSE, CRM, d, and EF values showed good agreement between the measured and predicted groundwater table depths. The values of these statistics were $0.04 \mathrm{~m}, 4 \%, 0.95$, and 0.78 , respectively. The identification of model parameters and the procedure of the model calibration and validation were presented by Sojka et al. 2019 [19].

The model parameters were identified on the basis of soil properties (Table 1), technical parameters of the drainage network and crop characteristics (Table 2). Soil water retention properties up to $-100 \mathrm{kPa}$ were determined using the Richards chambers, whereas for lower values of the pressure head using the method of water vapor pressure over a solution of sulfuric acid. The saturated hydraulic conductivity was determined using the method of a constant hydraulic water gradient. The soil package included in DRAINMOD was used to estimate the Green-Ampt infiltration model parameters, the drainage volume-water table depth, and the water upflux-water table depth relationships. Details of soil properties and drainage network parameters were presented by Sojka et al. [19]. The climate data included daily precipitation and daily minimum, average and maximum air temperatures. During the DRAINMOD simulation, daily precipitation was uniformly distributed over $6 \mathrm{~h}$ (15 to $21 \mathrm{~h}$ ) to obtain hourly precipitation according to the Skaggs [45] procedure. The ET value calculated by the Thornthwaite method was corrected using the monthly ET factors. In the first stage of research, 18 scenarios of the CD network functioning in the current climatic conditions were analyzed, assuming different meteorological conditions (dry, normal, and wet years-2014, 2017, and 2018), initial groundwater table conditions (groundwater table depth at $0.4 \mathrm{~m}, 0.6 \mathrm{~m}$, and $0.7 \mathrm{~m}$ on 1 st of March-start of the simulation), drainage network parameters (drainage spacing 7 and $14 \mathrm{~m}$ ), and the FD drainage practice.

Table 2. Input parameters and simulation scenarios description.

\begin{tabular}{|c|c|}
\hline Input Parameters & Value \\
\hline Drain depth $(\mathrm{m})$ & 0.90 \\
\hline Drain spacing $(\mathrm{m})$ & $7 ; 14$ \\
\hline Drain diameter $(\mathrm{m})$ & 0.05 \\
\hline Effective radius of drains $(\mathrm{m})$ & 0.011 \\
\hline Depth to impermeable layer (m) & 4.00 \\
\hline Drainage coefficient $\left(\mathrm{cm} \cdot \mathrm{day}^{-1}\right)$ & 1.4 \\
\hline Maximum surface storage $(\mathrm{m})$ & 0.005 \\
\hline Kirkham's depth for flow to drains $(\mathrm{cm})$ & 0.5 \\
\hline Crop type & spring wheat \\
\hline Planting date & 20th of March \\
\hline Growing season length (days) & 120 \\
\hline Max. effective root depth $(\mathrm{m})$ & 0.40 \\
\hline ET monthly factors & 0.6 (March); 0.7 (April); 0.9 (May); 1.0 (June-July); 0.9 (August); 0.8 (September) \\
\hline \multicolumn{2}{|l|}{ Simulation scenarios description } \\
\hline Years & 2014, 2017, 2018 \\
\hline Simulation period & 1st of March-30th of September \\
\hline CD start date & $\begin{array}{l}\text { 1st of March; 15th of March; 1st of April } \\
\text { 15th of April }\end{array}$ \\
\hline Initial ground water table (m b.s.l.) & $0.40 ; 0.60 ; 0.80$ \\
\hline Damming height for CD (m b.s.l.) & 0.50 \\
\hline Climate change scenarios & RCP 4.5 \\
\hline Time perspective & Near future (2021-2050); Far future (2071-2100) \\
\hline
\end{tabular}


The precipitation and minimum and maximum temperature for near and far future periods (2021-2050 and 2071-2100) were input data in DRAINMOD model. In these studies, 180 simulations were carried out, including 72 simulations for CD and 18 for FD for each time period, 2021-2050 (near future) and 2071-2100 (far future) (Table 2).

The results of simulation are daily values of depth to groundwater table (DTWT), surface runoff (SR) and subsurface drainage (SD). The calculation scheme is presented in Figure 3. The statistical differences between the values of mean DTWT, SR, and SD in different scenarios in the present, near and far future, were assessed using a non-parametric analysis of the variance performed using the STATISTICA 13.1 PL statistical software, with Kruskal-Wallis (K-W) and Dunn's tests as post hoc procedures $(p \leq 0.05)$.

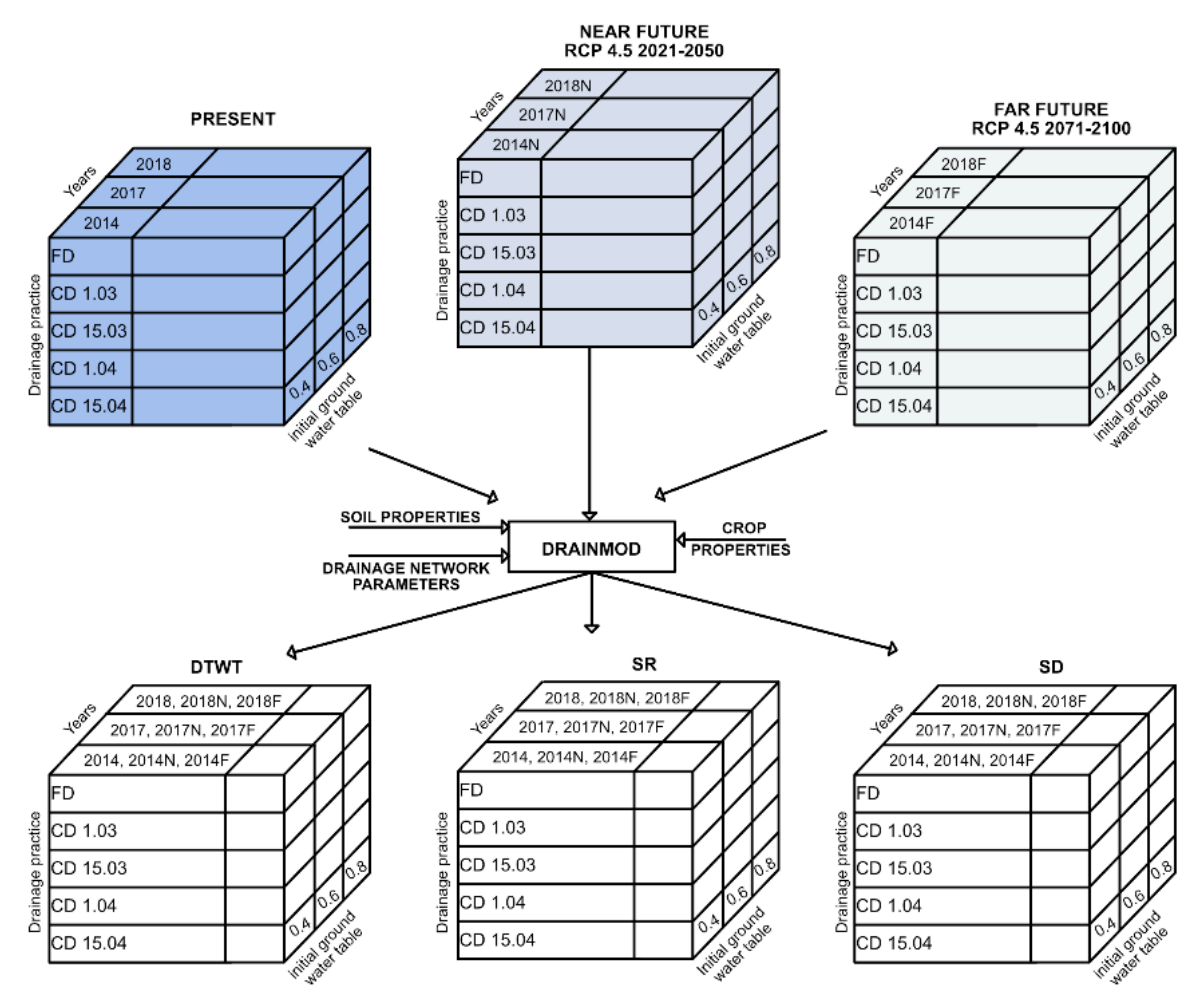

Figure 3. Simulation procedure (FD-free drainage, CD-Control drainage, SR-surface runoff, SD-subsurface drainage, RCP-Representative Concentration Pathway, DTWT-depth to groundwater table, N-near future, F-far future).

\subsection{Climate Change Projection}

Climate change projection for the study area was determined by using the resources of the climateimpact.sggw.pl Geoportal [51,52]. The Geoportal was developed in the framework of the Polish-Norwegian Research Programme, within the project CHASE-PL (Climate Change Impact on Selected Sectors in Poland). Temperature and precipitation projections for two time horizons have been used: near future (2021-2050) and far future (2071-2100). The maps of climate projection for precipitation, minimum, and maximum temperature interpolated on a $5 \mathrm{~km}$ grid are available for the whole area of Poland [51,52]. Projections of climate change in Poland were developed on the basis of downscaling of General Circulation Models (GCMs). In the CHASE-PL project, the analyses were carried out using a set of climate projections comprising nine regional climate model outputs (bias-corrected and downscaled to a $5 \mathrm{~km} \times 5 \mathrm{~km}$ grid) stemming from the Coordinated Downscaling Experiment-European Domain (EURO-CORDEX) ensemble [53]. In this study, the data from the RCP 4.5 scenario representing intermediate greenhouse gas emissions were taken into account. The data concerning the projection of seasonal temperature and precipitation changes in the near (Table 3) and 
far future (Table 4) were used. The obtained results indicate that in the analyzed area there will be an increase in temperature and precipitation. In the near future, in spring and summer, the average temperature will increase by about $1.0^{\circ} \mathrm{C}$ and in the far future by $1.8^{\circ} \mathrm{C}$ (Table 3). Both in the near and far future, in spring, and autumn, it is expected that seasonal precipitation will increase by 9.11 and $2.47 \%$ as well as by 16.44 and $3.76 \%$, respectively (Table 4 ).

Table 3. Projection of average, minimum and maximum temperature $\left({ }^{\circ} \mathrm{C}\right)$ increase for near future (2021 to 2050) and far future (2071 to 2100) compared to the historical period (1971 to 2000).

\begin{tabular}{ccccccc}
\hline \multirow{2}{*}{ Period $^{\mathbf{1}}$} & \multicolumn{3}{c}{ Near Future } & \multicolumn{3}{c}{ Far Future } \\
\cline { 2 - 7 } & $\mathbf{T}_{\min }$ & $\mathbf{T}_{\text {average }}$ & $\mathbf{T}_{\max }$ & $\mathbf{T}_{\min }$ & $\mathbf{T}_{\text {average }}$ & $\mathbf{T}_{\max }$ \\
\hline Winter & 1.32 & 1.25 & 1.18 & 2.68 & 2.50 & 2.31 \\
\hline Spring & 0.87 & 0.86 & 0.74 & 1.99 & 1.91 & 1.84 \\
\hline Summer & 1.21 & 1.08 & 0.88 & 1.69 & 1.67 & 1.52 \\
\hline Autumn & 1.17 & 1.15 & 1.05 & 1.93 & 1.89 & 1.86 \\
\hline Annual & 1.08 & 1.02 & 1.02 & 2.11 & 1.97 & 1.78 \\
\hline
\end{tabular}

1 Winter (December, January, February), Spring (March, April, May), Summer (June, July, August). Autumn (September, October, November).

Table 4. Projection of precipitation increase (\%) for near future (2021 to 2050) and far future (2071 to 2100) compared to the historical period (1971 to 2000).

\begin{tabular}{ccc}
\hline Period $^{\mathbf{1}}$ & Near Future & Far Future \\
\hline Winter & 6.81 & 19.79 \\
\hline Spring & 9.11 & 16.44 \\
\hline Summer & 2.47 & 3.76 \\
\hline Autumn & 3.52 & 8.03 \\
\hline Annual & 5.98 & 10.15
\end{tabular}

${ }^{1}$ Winter (December, January, February), Spring (March, April, May), Summer (June, July, August). Autumn (September, October, November).

The gradual and variable approaches were applied to modify the historical daily climate data (2014, 2017, and 2018). The gradual algorithm was used for temperature. The modification involved adding the values specified in Table 3 to the minimum and maximum daily temperatures. The gradual modifications did not change the timing of extreme climatic events. Thus, drought and extreme rainfall events in the future climate for the near and far future occurred in the same frequency as in the historical data. In Poland, it is assumed that the frequency and duration of droughts and extreme precipitation will increase. The variable modification of the precipitation was made to achieve more dry days, greater contiguous dry-day durations, and more intense rainfall events on the basis of methods proposed by Harrison et al. [39]. In this method, small, medium, and large rainfall events were separately manipulated by different seasonal factors. The seasonal factors (CsP) were calculated on the basis of the precipitation change (\%) values presented in Table 4. For example, the CsP value for spring in the near future is 1.0911, representing a $9.11 \%$ increase in rainfall. Subsequently, on the basis of daily precipitation data from 1992-2018 for spring, summer and autumn seasons, the percentile values were computed. On the basis of the percentile values, the daily precipitation data were classified into three groups. Small, medium, and large daily precipitation (Pi) were multiplied by different factors (FPi) to achieve the required overall seasonal change in precipitation: 


$$
\mathrm{FP}_{\mathrm{i}}=\left\{\begin{array}{lr}
\left(0, \mathrm{C}_{\mathrm{sP}}-0.5\right) & \mathrm{P}_{\mathrm{i}}<40 \text { th percentile } \\
\left(\mathrm{C}_{\mathrm{sP}}-0.5, \mathrm{C}_{\mathrm{sP}}+0.1\right) & \text { 40th percentile } \leq \mathrm{P}_{\mathrm{i}} \leq 90 \text { th percentile } \\
\left(\mathrm{C}_{\mathrm{sP}}+0.3, \mathrm{C}_{\mathrm{sP}}+0.5\right) & \mathrm{P}_{\mathrm{i}}>40 \text { th percentile }
\end{array}\right.
$$

The Solver routine in Microsoft Excel was used to optimize FPi across years y and percentiles p:

$$
\frac{\sum_{\mathrm{y}=1}^{27} \sum_{\mathrm{p}=1}^{3} \mathrm{~F}_{\mathrm{Pi}} \mathrm{P}_{\mathrm{i}}}{\sum_{\mathrm{y}=1}^{27} \sum_{\mathrm{p}=1}^{3} \mathrm{P}_{\mathrm{i}}}=\mathrm{C}_{\mathrm{sP}}
$$

In this way, on the basis of the series of historical meteorological data (2014, 2017, and 2018), a series of meteorological data for the near $(2014 \mathrm{~N}, 2017 \mathrm{~N}$, and $2018 \mathrm{~N})$ and far future $(2014 \mathrm{~F}, 2017 \mathrm{~F}$, and 2018 F) were generated.

\section{Results}

The analysis of the effectiveness of CD solutions is presented in relation to the periods from March to September for the years 2014, 2017, and 2018, which are characteristic in terms of precipitation. According to the methodology presented above, daily precipitation was modified in order to present the functioning of drainage networks and the effectiveness of CD solutions in the near and far future. In this way, new daily rainfall series were created for the period from March to September for the near (2014N, 2017N, and 2018N) and far future (2014F, 2017F, and 2018F). The modification of precipitation caused that in all analyzed years the length of rain-free periods increased and the number of days with daily precipitation above $0.1 \mathrm{~mm}$ was reduced. The number of days with precipitation for 2014, 2017, and 2018 will decrease by 33\%,43\%, and 49\% respectively in the future. In the near future, between March and September, rainfall will increase by $4 \%$ to $13 \%$, on average by $8 \%$. A slightly larger increase in precipitation will occur in the far future from $7 \%$ to $16 \%$, on average by $11 \%$. However, in the case of maximum daily precipitation, climate change in the near and far future will result in an increase of around $50 \%$. The results of rainfall modification in individual months are presented in Table 5.

Table 5. Results of precipitation modification (numerator presents the values of precipitation sums and maximum daily precipitation, whereas the denominator shows the number of days with daily precipitation above $0.1 \mathrm{~mm}$ ).

\begin{tabular}{cccccccccc}
\hline Years & $\mathbf{2 0 1 4}$ & $\mathbf{2 0 1 4 N}$ & $\mathbf{2 0 1 4 F}$ & $\mathbf{2 0 1 7}$ & $\mathbf{2 0 1 7 N}$ & $\mathbf{2 0 1 7 F}$ & $\mathbf{2 0 1 8}$ & $\mathbf{2 0 1 8 N}$ & $\mathbf{2 0 1 8 F}$ \\
\hline \multirow{2}{*}{ March } & $45.9-14.0$ & $46.5-22.3$ & $50.0-23.3$ & $37.5-8.8$ & $41.4-14.0$ & $44.1-14.6$ & $29.4-7.7$ & $21.4-6.0$ & $23.6-6.6$ \\
& 10 & 9 & 9 & 11 & 5 & 5 & 14 & 8 & 8 \\
\hline \multirow{2}{*}{ April } & $46.8-13.5$ & $54.1-21.5$ & $57.6-22.5$ & $33.9-8.0$ & $30.8-12.7$ & $33.3-13.3$ & $28.1-7.1$ & $19.1-5.5$ & $21.1-6.1$ \\
& 11 & 9 & 9 & 13 & 9 & 9 & 13 & 7 & 7 \\
\hline \multirow{2}{*}{ May } & $67.9-19.5$ & $82.6-31.0$ & $87.6-32.5$ & $32.9-13.7$ & $35.5-21.8$ & $37.9-22.8$ & $16.6-9.5$ & $18.8-15.1$ & $19.9-15.8$ \\
& 15 & 10 & 10 & 12 & 6 & 6 & 8 & 4 & 4 \\
\hline \multirow{2}{*}{ June } & $30.0-5.5$ & $17.6-3.7$ & $18.0-3.8$ & $87.0-34.9$ & $95.9-53.2$ & $97.0-53.7$ & $22.8-7.1$ & $14.3-4.8$ & $14.5-4.9$ \\
& 12 & 6 & 6 & 17 & 8 & 8 & 9 & 5 & 5 \\
\hline \multirow{2}{*}{ July } & $51.6-16.1$ & $59.9-24.5$ & $60.6-24.8$ & $127.1-19.9$ & $141.6-30.3$ & $143.2-30.6$ & $81.3-45.5$ & $110.7-69.4$ & $111.8-70.0$ \\
& 11 & 8 & 8 & 18 & 13 & 13 & 10 & 6 & 6 \\
\hline \multirow{2}{*}{ August } & $91.6-38.5$ & $104.4-58.7$ & $105.6-59.2$ & $97.0-27.4$ & $119.4-41.8$ & $120.6-42.1$ & $9.8-2.9$ & $2.0-2.0$ & $2.1-2.1$ \\
& 18 & 9 & 9 & 13 & 10 & 10 & 9 & 1 & 1 \\
\hline \multirow{2}{*}{ September } & $35.5-6.1$ & $27.5-4.8$ & $29.2-5.1$ & $40.1-16.5$ & $49.7-25.3$ & $51.4-26.1$ & $40.7-18.2$ & $50.6-27.9$ & $52.4-28.8$ \\
& 11 & 8 & 8 & 14 & 5 & 6 & 8 & 5 & 5 \\
\hline March- & $369.3-38.5$ & $392.6-58.7$ & $408.5-59.2$ & $455.5-34.9$ & $514.3-53.2$ & $527.5-53.7$ & $228.7-45.5$ & $236.9-69.4$ & $245.4-70.0$ \\
September & 88 & 59 & 59 & 98 & 56 & 57 & 71 & 36 & 36 \\
\hline
\end{tabular}

In accordance with the research scheme presented in the methodology (Figure 3), a series of simulations was carried out to show how the drainage network will be functioning in the future and what the effectiveness of CD solutions will be. The influence of climate change on the functioning of 
drainage networks was presented in relation to the depth of groundwater table, subsurface outflows from drainage networks, and surface outflows.

\subsection{Groundwater}

According to the results of the simulations performed, at present in the fields with traditional drainage systems of $7 \mathrm{~m}$ spacing, the groundwater table is above the drainage network level from 27 to 51 days, on average for 40 days (Figure 4a) in the period from 1st of March to 30th of September. In the fields equipped with the drainage network of $14 \mathrm{~m}$ spacing, the groundwater table remains above the drainage network level for the period of 40 to 66 days, on average 53 days (Figure $4 \mathrm{~b}$ ). The predicted climate changes in temperature and amount of precipitate imply that the period in which the groundwater table will be above the drainage network level will get shorter. In the fields equipped with the drainage network of $7 \mathrm{~m}$ spacing the groundwater table will be above the drainage network level on average for 35 and 33 days in the near and far future, respectively. Moreover, in the fields with the drainage network of $14 \mathrm{~m}$ spacing, the period in which the groundwater table will be above the drainage network level will shorten to 49 and 46 days, on average, for the near and far future, respectively (Figure $4 b$ ).

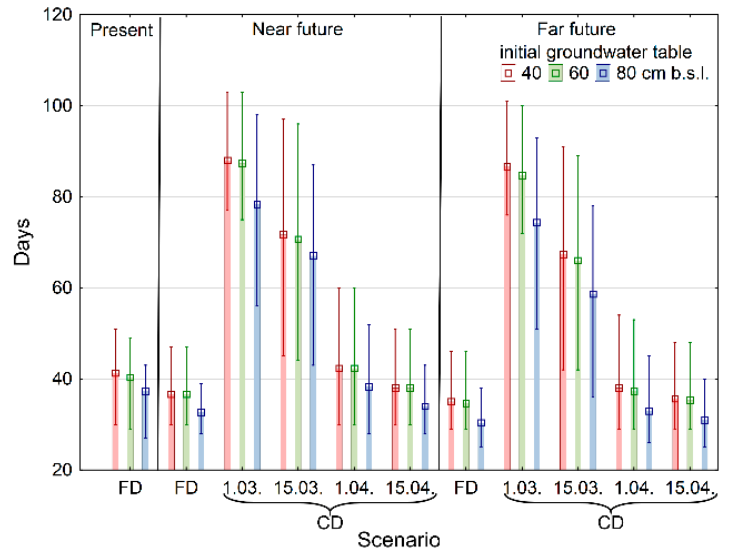

(a)

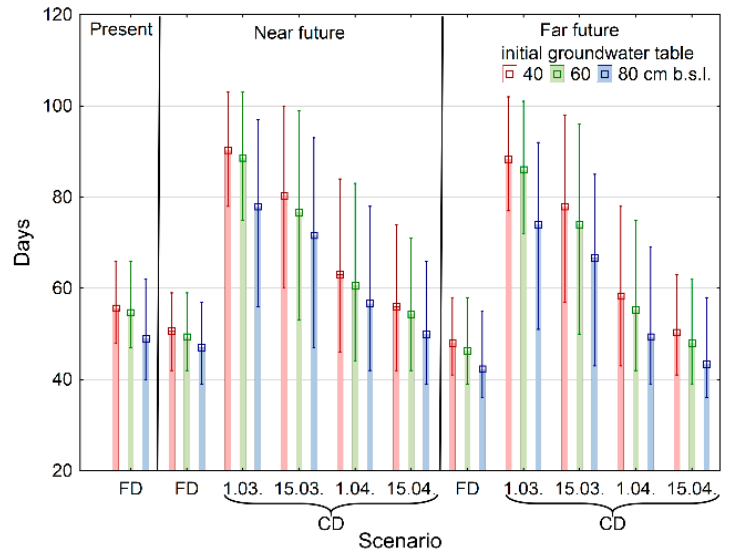

(b)

Figure 4. Impact of climate change on the time of groundwater location above the level of the drainage network with spacing of $7 \mathrm{~m}$ (a) and $14 \mathrm{~m} \mathrm{(b)} \mathrm{(bar} \mathrm{charts} \mathrm{with} \mathrm{error} \mathrm{bars} \mathrm{show} \mathrm{the} \mathrm{average} \mathrm{values,}$ as well as the minimum and maximum values for the years 2014, 2017, and 2018).

The simulation has shown that the use of $\mathrm{CD}$ solutions induced changes in the groundwater dynamics. The best results were obtained for the scenarios with the start of blocking the outflow on the 1st of March. The use of CD solution in the near future on the drainage network with spacing of $7 \mathrm{~m}$ implies that the groundwater will be higher than the drainage network level for 56 to 103 days (on average 85 days) (Figure 4a). In the far future, this time may be reduced by three days on average. The implementation of CD solutions from the 15th of March in the drainage network with spacing of $7 \mathrm{~m}$ means that groundwater table will be above the drainage network level on average for 70 days and 64 days in the near and far future (Figure 4a). The start of blocking the outflow on the 1st or 15th of April, both in the near and far future, will have little effect on the groundwater table dynamics. The time for the groundwater table to be above the drainage network level, for the scenarios of the 1st and 15th of April, will be, on average, 41 and 37 days for the near future and 34 and 36 days for the far future. These values are at a similar or even lower level than those presently observed in the FD network. The best results from CD implementation in the $14 \mathrm{~m}$ spacing drainage network will be achieved for the scenarios with the start of blocking the outflow on the 1st of March (Figure 4b). The average time of groundwater table remaining above the drainage network level will be similar as 
in the drainage network with spacing of $7 \mathrm{~m}$. On the other hand, when CD solutions are applied from the 15th of March, the periods of groundwater table being above the drainage network level in the near and far future will be 76 and 73 days, respectively, and will be about 8 days longer than for the drainage network with $7 \mathrm{~m}$ spacing. The start of blocking the outflow in April will cause that the time of groundwater table remaining above the level of the drainage network will be from 49 to 53 days and from 46 to 47 days, in the near and far future, respectively (Figure $4 \mathrm{~b}$ ). Implementation of CD solutions in April is less effective, the groundwater tables are at the level presently observed in the FD network.

At present, taking into account the FD drainage network with spacing of $7 \mathrm{~m}$, the groundwater level varied between 118 and $128 \mathrm{~cm}$ b.s.l. (Figure 5a), with an average value of $123 \mathrm{~cm}$ b.s.l. However, in the drainage network with spacing of $14 \mathrm{~m}$, the groundwater tables were located at the level of 113 to $126 \mathrm{~cm}$ b.s.l. (Figure 5b), with an average value of $118 \mathrm{~cm}$ b.s.l. In the near and far future, due to the increase in air temperatures and precipitation as well as changes in the precipitation patterns, the average groundwater level in the drained fields will decrease from 2 to $5 \mathrm{~cm}$. The differences between the average groundwater levels for FD at present and in the near and far future are statistically insignificant. The application of CD solutions when starting to block the outflow on the 1st of March will allow the average groundwater level to increase in the near future on average by 26 and $22 \mathrm{~cm}$ in the fields equipped with the drainage network with spacing of 7 and $14 \mathrm{~m}$, respectively. Slightly smaller effects will be achieved in the far future for this type of solution, on average by about $2 \mathrm{~cm}$. Smaller effects in terms of raising the groundwater level can be achieved in the near and far future by starting to block the outflow on the 15th of March, with the average of 10 and $8 \mathrm{~cm}$ and 12 and $10 \mathrm{~cm}$ for the drainage network of 7 and $14 \mathrm{~m}$ spacing, respectively. The better effects of the drainage network with spacing of $14 \mathrm{~m}$ result from slower drainage of water from the field in the period preceding the blocking of outflow in comparison with the drainage network with spacing of $7 \mathrm{~m}$. The differences between average groundwater levels for FD and CD implemented from the 1st and 15th of March were statistically significant for the near and far future.

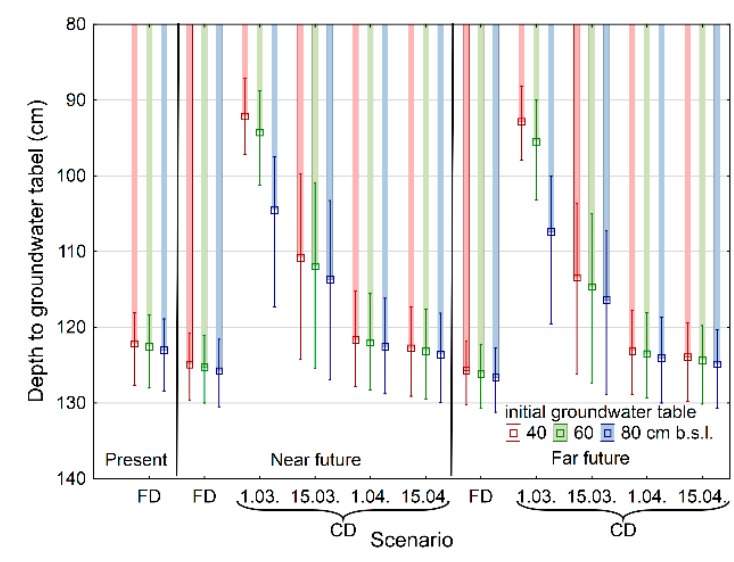

(a)

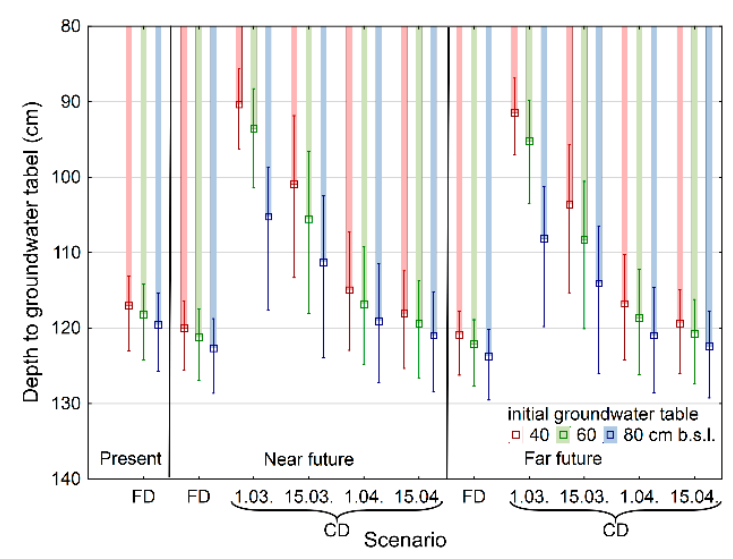

(b)

Figure 5. Depth to groundwater table in conventional network (FD-free drainage) and for the various $\mathrm{CD}$ scenarios of the $7 \mathrm{~m} \mathrm{(a)} \mathrm{and} 14 \mathrm{~m} \mathrm{(b)} \mathrm{drainage} \mathrm{network} \mathrm{spacing} \mathrm{in} \mathrm{the} \mathrm{near} \mathrm{and} \mathrm{far} \mathrm{future,} \mathrm{compared}$ to the results of the conventional network at present. Bar charts with error bars show the average values, as well as the minimum and maximum values for the years 2014, 2017, and 2018.

The implementation of CD solutions at the start of blocking the outflow in April, in the near and far future will make it possible to maintain the groundwater table at a level similar to that presently observed in the free drainage network (FD) (Figure 5). It should be noted, however, that variations between individual years (dry and wet) will be more pronounced in the near and far future than at present. The obtained results indicate that the effects of raising the groundwater table in the field for CD solutions implemented from the 1st of March are mainly influenced by the initial 
conditions (groundwater depth) together with the delay in blocking the outflow from the drainage network. The effect of the initial conditions decreases. However, the effect of meteorological conditions is most visible in the scenario with the starting date of blocking the outflow on the 15th of March. Generally, the meteorological conditions have a greater influence on the CD effects than the initial depth of groundwater.

The impact of individual CD solution for the $7 \mathrm{~m}$ and $14 \mathrm{~m}$ spacing drainage networks on the groundwater table rise in individual months in the near and far future is presented in Figure 6. The results obtained indicate that the best effects in terms of groundwater table rise are obtained when the initial groundwater level is $0.4 \mathrm{~m}$ b.s.l. Moreover, the groundwater table rise starts on the 1st of March. In the period from March to September in the near future, in the drainage network with spacing of $7 \mathrm{~m}$, the average increase in groundwater table will be from 28 to $34 \mathrm{~cm}$ (Figure 6a) and for the drainage network with spacing of $14 \mathrm{~m}$, from 24 to $32 \mathrm{~cm}$ (Figure 6b). In the far future, the effects of using CD will be at a slightly lower level. In the case of the CD scenarios with the start of blocking the outflow on the 1st of March, the initial conditions, i.e., the groundwater level at the beginning of the simulation period, have a pronounced impact on the effects of raising the groundwater table. In the case of drainage networks with spacing of $7 \mathrm{~m}$, blocking the outflow from the 15th of March will result in an average increase in the groundwater table by about 2.5 times smaller than that obtained for the CD 1st March scenario. A smaller reduction of the impact on groundwater levels caused by the delay of CD implementation is predicted for the drainage network with $14 \mathrm{~m}$ spacing. The start of blocking the outflow from the network on the 15th of March will be approximately 1.5 times less effective on average than for the scenarios of blocking it from the 1st of March. If CD solutions are used to start blocking the drain on the 1st or 15th of April, the maximum groundwater table rise will be $6 \mathrm{~cm}$. There will also be situations where the groundwater table may be lowered by approximately $6 \mathrm{~cm}$ compared to that presently observed in the drainage networks.

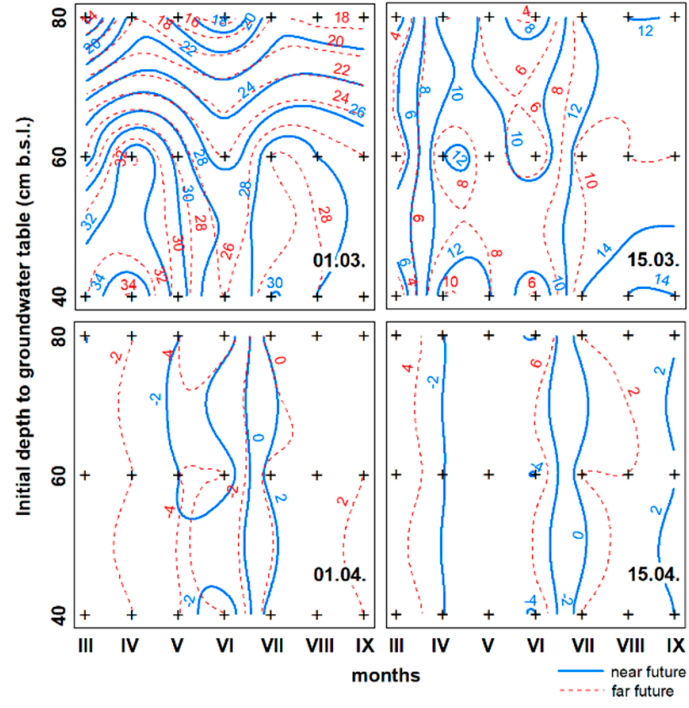

(a)

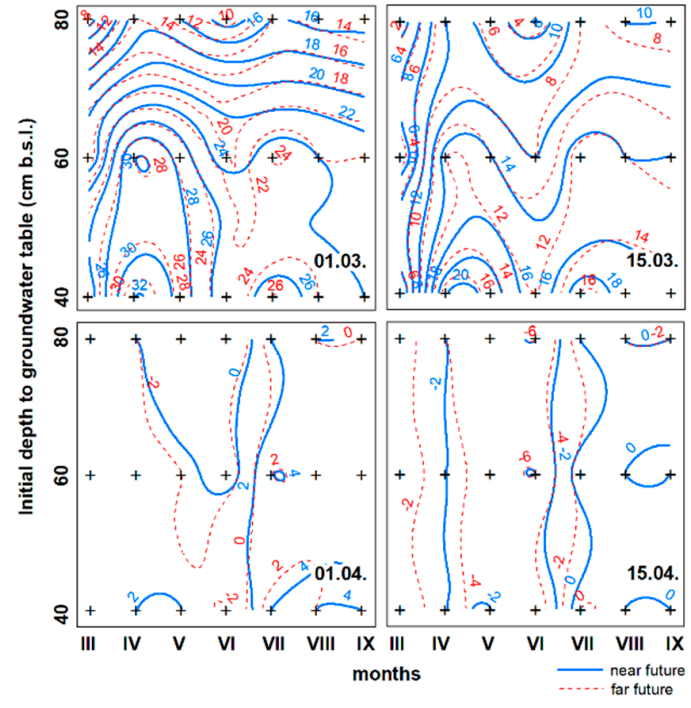

(b)

Figure 6. Average increases in groundwater tables in successive months for near and far future with different dates for blocking the outflow from the network with spacing of $7 \mathrm{~m} \mathrm{(a)}$ and $14 \mathrm{~m} \mathrm{(b)}$.

\subsection{Subsurface Outflow}

According to the recent trends in water management in agriculture, much attention is paid to the subsurface outflows from drainage fields. Successful management of these outflows may lead to elevation of the groundwater table and improvement of soil moisture conditions. 
At present, the subsurface outflows from the FD network from March to September are at the level of 63,53 and $28 \mathrm{~mm}$ (spacing of $7 \mathrm{~m}$ ) and 59, 42, and $25 \mathrm{~mm}$ (spacing of $14 \mathrm{~m}$ ), respectively, relative to the initial groundwater conditions of $0.4,0.6$, and $0.8 \mathrm{~m}$ b.s.l. (Figure 7 ). In the near future, the subsurface outflow from the FD network will be at a slightly lower level. Depending on the initial conditions, the outflows will be on average of 59, 42, and $24 \mathrm{~mm}$ (7 m spacing) and 55, 38, and $21 \mathrm{~mm}$ (14 $\mathrm{m}$ spacing). The subsurface outflows from the FD network will also be reduced in the far future. Therefore, the amount of available water for use will be reduced. The differences between the outflow values from the FD drainage network at present and for the near and far future were statistically insignificant. Implementation of CD solutions from the 1st of March will allow the best results to be achieved in terms of reduction of subsurface outflow from the drainage network both in the near and far future. Slightly better effects in terms of reduction of subsurface outflow from the network will be possible to achieve for the $14 \mathrm{~m}$ drainage network spacing than for $7 \mathrm{~m}$ spacing. If the groundwater table is at the level of $0.8 \mathrm{~m}$ b.s.l., it is possible to reduce the outflow from the drainage network totally when blocking the outflow from the 1st of March. The results indicate that early start of CD activities is particularly important for $7 \mathrm{~m}$ network spacing. Delay in the blocking of the outflow to the 15th of March will result in outflows from the network at the initial groundwater level of $0.4 \mathrm{~m}$ b.s.l. of $44 \mathrm{~mm}$ on average. In general, the differences between the outflows for FD and the scenarios with blocking outflows from the drainage network from the 1st and 15th of March are statistically significant both for the near and far future. The largest outflows from the drainage network occur in the case of CD scenarios with the start of blocking the outflow in April. In the climatic conditions of Poland, outflows from the drainage network mainly take place in March. It should be noted that a larger reduction of outflow for each CD scenarios is achieved for the drainage networks with spacing of $14 \mathrm{~m}$.

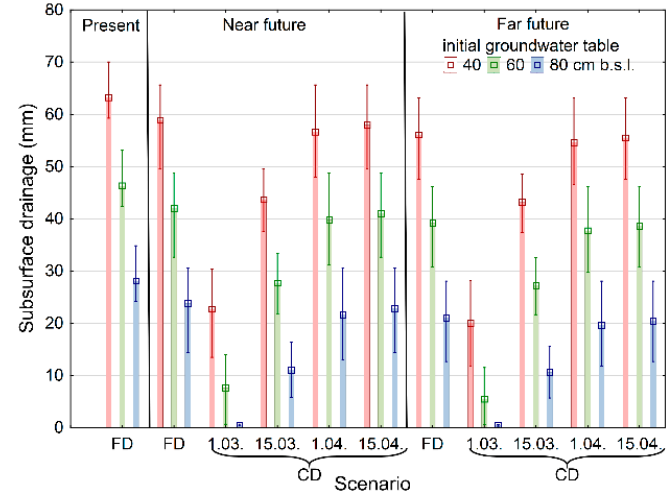

(a)

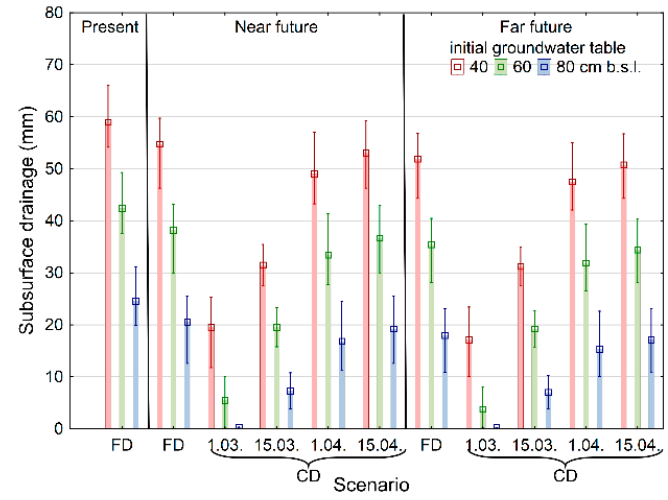

(b)

Figure 7. Subsurface outflows from free drainage network and with the use of various CD scenarios for the present and for the near and far future for drainage networks with spacings of $7 \mathrm{~m}(\mathbf{a})$ and $14 \mathrm{~m}(\mathbf{b})$. Bar charts with error bars show the average values, as well as the minimum and maximum values for the years 2014, 2017, and 2018.

Changes in thermal conditions, and in particular in the amount of precipitation in the near and far future, will affect the functioning of drainage systems in Poland. In general, in FD networks, regardless of the initial conditions of the groundwater table, there will be a tendency to decrease the subsurface outflows from drainage networks (Figure 8). The decrease of outflow from FD drainage networks will be at the average level of $11 \%$ and $17 \%$ as well as $12 \%$ and $18 \%$ in the near and far future, respectively, for the networks with spacing of 7 and $14 \mathrm{~m}$. However, it should be noted that in the wet years $(2017 \mathrm{~N}$ and 2017F) there may be a slight increase in the outflows from the drainage networks at the level of $18 \%$ and $10 \%$ in the near and far future. The average reduction of outflow from drainage networks at the start of blocking outflow on the 1st of March for the drainage networks with spacing of 7 and $14 \mathrm{~m}$ will be $82 \%$ and $85 \%$ on average and $84 \%$ and $87 \%$ in the near and far future, respectively. Around twice as 
small effects will be achieved for CD scenarios when blocking the outflow is started on the 15th of March. In the case of other scenarios, the reduction of outflows from the $7 \mathrm{~m}$ network spacing will be at an average level of $8 \%$ to $30 \%$ and for the $14 \mathrm{~m}$ network spacing at an average level of $10 \%$ to $38 \%$.

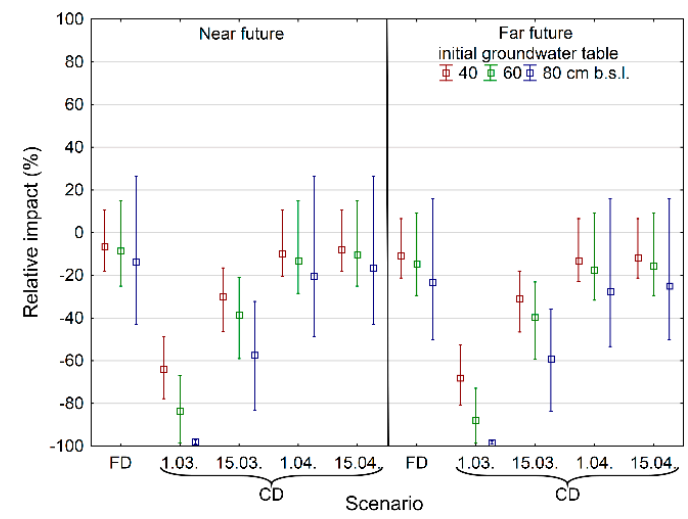

(a)

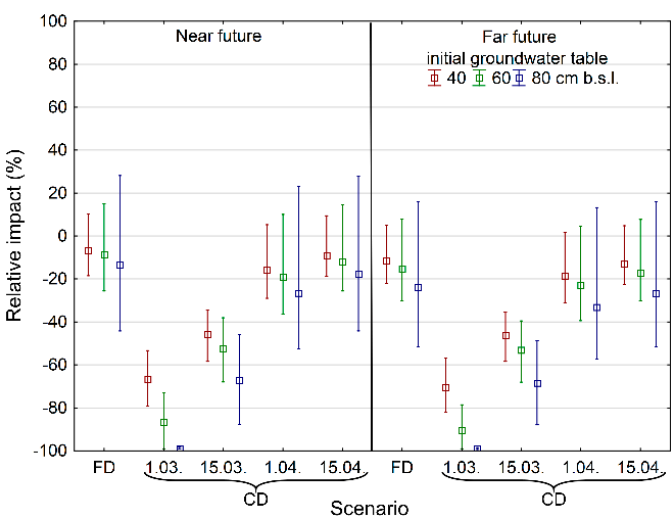

(b)

Figure 8. Changes in subsurface outflows from $7 \mathrm{~m} \mathrm{(a)}$ and $14 \mathrm{~m} \mathrm{(b)} \mathrm{spacing} \mathrm{drainage} \mathrm{networks} \mathrm{for} \mathrm{the}$ FD and CD scenarios in the near and far future, in relation to subsurface outflows from FD networks. Bar charts with error bars show the average values, as well as the minimum and maximum values for the years 2014, 2017, and 2018.

\subsection{Surface Runoff}

One of the important components of the water balance is surface runoff from the field. It is particularly interesting for increasing rainfall intensity in the near and far future due to climate change. The results of the simulation show that in the present climatic conditions in the period from March to September, the surface runoffs are small and range from about 2 to $3 \mathrm{~mm}$ (Figure 9). The increase in rainfall intensity in the near and far future will result in an increase in the proportion of surface runoff from the fields. Calculations have shown that regardless of the scenarios of the FD or CD drainage network, in the near future outflows will range from approximately 7.5 to approximately $12.5 \mathrm{~mm}$ (9.5 $\mathrm{mm}$ on average) and in the far future from 7.3 to $11.8 \mathrm{~mm}$ (9.0 $\mathrm{mm}$ on average). These values are almost five times higher than at present (statistically significant difference), which means that their effects need to be seriously considered from the point of view of erosion and nitrogen and phosphorus uptake into surface waters.

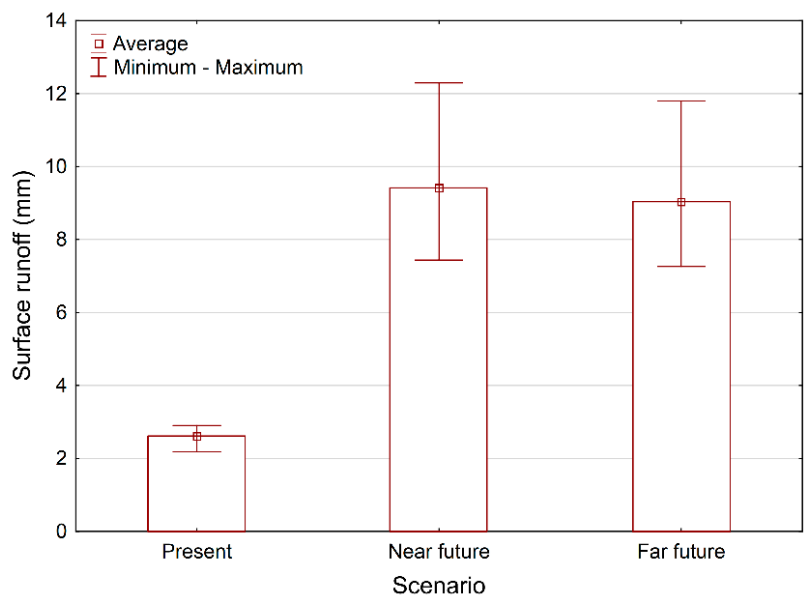

Figure 9. Surface outflows from drained arable land as a result of the current situation and for the near and far future. Bar charts with error bars show the average values, as well as the minimum and maximum values for the years 2014, 2017, and 2018. 


\section{Discussion}

Analyses of the functioning of the drainage network in the near and far future indicate that the effectiveness of the use of $C D$ solutions will decrease with respect to the present situation. However, Pease et al. [54] indicated the benefits of controlled drainage will still be evident under projected future climate. With respect to the previous results on the effectiveness of CD solutions [19], in the future, the impact on groundwater will be reduced from 2 to $8 \mathrm{~cm}$ in the case of $7 \mathrm{~m}$ spacing drainage networks and from 4 to $10 \mathrm{~cm}$ in the case of scenarios with the start of blocking the outflow on 1st and 15th of March. On the other hand, for networks with a $14 \mathrm{~m}$ spacing, the decrease in the effectiveness of the impact on the ground water level will be greater for the start date of the outflow blocking on 1st of March from 10 to $12 \mathrm{~cm}$ than for the start date of blocking the outflow on 15th of March from 6 to $8 \mathrm{~cm}$. The CD treatment produced significantly higher evapotranspiration and soil water content than the conventional drainage treatment during the dry years [55].

The results also indicated that $C D$ practice can reduce drainage outflow significantly [19]. Pease et al. [54] have indicated that CD efficiency was projected to increase during summer of a $42.7 \%$ reduction in subsurface drainage discharge for RCP 4.5 under late-century climate conditions. Although tile drainage volume varied amongst the different climate scenarios, $\mathrm{NO}_{3}{ }^{-}-\mathrm{N}$ loss and flow-weighted average $\mathrm{NO}_{3}{ }^{-}-\mathrm{N}$ concentration will increase [56]. Thus, also the water quality in waterbodies can be improved. In a model study, Gilliam and Skaggs [57] have reported that the controlled drainage resulted in the reduction of the nitrate efflux by as much as $34 \%$ but the reduction varied with soil and management conditions. Wesström [58] in the field experimental project has pointed out a significant total reduction in nitrate losses. In humid continental climates Sunohara et al. [59,60] have confirmed that the $\mathrm{CD}$ retrofitted to existing tile drainage networks can effectively reduce tile drainage water, $\mathrm{NO}_{3}{ }^{-}-\mathrm{N}, \mathrm{NH}_{4+}-\mathrm{N}, \mathrm{DRP}$, total $\mathrm{P}$, and fecal indicator bacteria fluxes to surface waterbodies. The obtained results indicate that the decrease in the effectiveness of the impact of $C D$ solutions may not allow proper water conditions to be ensured during the whole period of plant growth. Baule et al. [61] have pointed out that $C D$ systems alone will not be able to mitigate the effects of climate change in agriculture. Only the combination of $\mathrm{CD}$ solutions and subirrigation systems will provide a viable climate adaptation strategy for agriculture [61]. According to Bonaiti and Borin [62], the advantage of the controlled drainage and subirrigation is that they can be used for continuous groundwater table management regardless of the weather conditions. In addition, attention should be paid to other possibilities for increasing soil water retention capacity [11]. Key factors for agriculture's climate change mitigation and adaptation are actions that will contribute to increasing water storage capacity of the soil and providing a larger zone for roots to grow, enabling them to access larger quantities of water and nutrients [63].

The results presented in the paper should be treated with caution because they concern specific conditions, i.e., the drainage object, which is characterized by specific geological conditions, soil conditions, topography, drainage network parameters, as well as hydrological and meteorological conditions. It is well known that the effectiveness of the $C D$ practice can vary across the region with the variation in environmental conditions and management practices [64]. The present research has shown that there will be a decrease in outflows from the drainage network in the period from March to September, with an increase in precipitation in that period. The use of $C D$ solutions will reduce outflows from drainage networks in the future. In terms of subsurface outflows, the results are generally within the ranges given by Skaggs et al. [29] and Cooke and Verma [26]. Wang et al. [56] have shown that under the future climate change the subsurface outflow will increase with increasing mean yearly precipitation. Similar results have been reported by Dayyani et al. [65] and Golmohammadi et al. [66]. Moreover, the studies by Mehan et al. [67] indicate a potential increase in surface and subsurface outflows due to climate change. This study shows that the potential growth of surface runoff should be taken into account in the future. Mehan et al. [67] have reported that more nutrient losses were predicted due to extreme precipitation events with surface outflow. Therefore, increasing number of 
studies have been focused on the methods of reducing the leaching of nitrogen and phosphorus from arable soils [68].

Duffková et al. [69] have suggested that on the basis of categorization of soil water availability, it is possible to propose location of irrigation systems, the regulation of drainage runoff or to consider controlled drainage. The main challenges are to establish a plan to manage CD systems, adapted to the existing environmental and climatic conditions and, above all, to the water requirements of crops and the dates of field work [70,71]. Most often, simple control rules resulting from natural climatic conditions, adjusted to agrotechnical works and water needs of plants, are established. The effectiveness of such systems can be increased by changing the control rules to more flexible ones, taking into account weather forecasting. In this way, the Climate Adaptive Drainage (CAD) system has been developed [72]. The CAD system consists of a controlled drainage system, a remote-controlled adjustable drain outlet, and a telemetry and database system to process the weather forecast.

\section{Conclusions}

The research carried out showed that the future climate change in the central-western part of Poland will extend the rain-free periods, the number of days with precipitation above $0.1 \mathrm{~mm}$ will decrease by $40 \%$ and the intensity of maximum daily precipitation will increase by $50 \%$. In addition, the increase in air temperatures will be accompanied by an increase in precipitation by an average of $8 \%$ and $11 \%$ in the near and far future. Assuming such climate change scenarios, the following detailed conclusions concerning the functioning of drainage networks and $\mathrm{CD}$ solutions have been formulated on the basis of the conducted analyses:

- in fields with FD systems, a reduction of groundwater table of 2 to $5 \mathrm{~cm}$ on average is expected in the near and far future in relation to the present conditions,

- $\quad$ an increase in the variation in water levels between wet and dry years is to be expected in the near and far future,

- the time of the groundwater table above the drainage network will be reduced by 5 and 7 days and by 4 and 7 days respectively in the near and far future for networks with spacing of 7 and $14 \mathrm{~m}$,

- the sub-surface outflows will be reduced at the average level of $11 \%$ and $17 \%$ and $12 \%$ and $18 \%$ respectively in the near and far future for networks with spacing of 7 and $14 \mathrm{~m}$,

- the share of surface run-off from fields is expected to increase approximately fivefold in the future as a result of climate change compared to the present situation,

- regardless of the initial conditions of groundwater table, the best results from CD solutions were obtained for the scenarios with the start of blocking the outflow on the 1st of March and 15th of March,

- greater effects of $\mathrm{CD}$ will be achieved for the $7 \mathrm{~m}$ network spacing if the outflow from the drainage network is blocked on 1st of March, and for the $14 \mathrm{~m}$ network spacing if the outflow is blocked on 15th of March,

- the use of CD solutions in the near and far future will allow similar efficiency to be achieved in relation to groundwater table rise and reduction of subsurface outflow from the drainage network,

- using CD solutions in April in the near and far future will allow the groundwater table to be maintained at a level similar to that currently observed in the conventional network (free drainage, FD),

- the change of the date of blocking the outflow from the drainage network from 1st to 15th of March will result in a decrease in efficiency by an average of 2.5 and 1.5 times in the case of drainage networks with spacing of $7 \mathrm{~m}$ and $14 \mathrm{~m}$.

In the future, the research should be extended to other drainage fields around Poland, which are characterized by specific geological conditions, soil conditions, topography, drainage network parameters, as well as hydrological and meteorological conditions. Studies should be carried out to establish $\mathrm{CD}$ principles suitable for the crops grown and available agronomic techniques. 
Author Contributions: Conceptualization, M.S.; data curation M.K. and B.K.; formal analysis, M.S.; funding acquisition, M.S.; investigation, R.S., M.N., D.L., M.S., R.W., J.J., and B.K.; methodology, M.S.; project administration, M.S., R.W., and J.J.; software M.K.; supervision, M.S.; validation, M.S.; visualization, M.S., J.J., and R.W.; writing —original draft, M.S. All authors have read and agreed to the published version of the manuscript.

Funding: Work carried out within the framework of the project "Technological innovations and system of monitoring, forecasting and planning of irrigation and drainage for precise water management on the scale of drainage/irrigation system (INOMEL)" within the BIOSTRATEG3 program, financed by the Polish National Centre for Research and Development. Contract number BIOSTRATEG3/347837/11/NCBR/2017.

Conflicts of Interest: The authors declare no conflict of interest.

\section{References}

1. Sojka, M.; Jaskuła, J.; Wicher-Dysarz, J.; Dysarz, T. Analysis of selected reservoirs functioning in the Wielkopolska region. Acta Sci. Pol. Formatio. Circumiectus 2017, 16, 205-215. [CrossRef]

2. Sojka, M.; Jaskuła, J.; Wróżyński, R.; Waligórski, B. Application of Sentinel-2 satellite imagery to assessment of spatio-temporal changes in the reservoir overgrowth process-a case study: Przebędowo, West Poland. Carpath. J. Earth Env. 2019, 14, 39-50. [CrossRef]

3. Jaskuła, J.; Sojka, M.; Wicher-Dysarz, J. Analysis of the vegetation process in a two-stage reservoir on the basis of satellite imagery - a case study: Radzyny Reservoir on the Sama River. Rocz. Ochr. Środowiska 2018, 20, 203-220.

4. Wicher-Dysarz, J. Analysis of shear stress and stream power spatial distributions for detection of operational problems in the Stare Miasto Reservoir. Water 2019, 11, 691. [CrossRef]

5. International Commission on Irrigation and Drainage. Agricultural Water Management for Sustainable Rural Development-Annual Report 2017-2018; ICID: New Delhi, India, 2018.

6. Destouni, G.; Verrot, L. Screening long-term variability and change of soil moisture in a changing climate. J. Hydrol. 2014, 516, 131-139. [CrossRef]

7. Brown, I. Climate change and soil wetness limitations for agriculture: Spatial risk assessment framework with application to Scotland. Geoderma 2017, 285, 173-184. [CrossRef]

8. Łabędzki, L.; Bakk, B. Impact of meteorological drought on crop water deficit and crop yield reduction in Polish agriculture. J. Water Land Dev. 2017, 34, 181-190. [CrossRef]

9. Wagena, M.B.; Easton, Z.M. Agricultural conservation practices can help mitigate the impact of climate change. Sci. Total Environ. 2018, 635, 132-143. [CrossRef]

10. Wolfe, D.W.; DeGaetano, A.T.; Peck, G.M.; Carey, M.; Ziska, L.H.; Lea-Cox, J.; Kemanian, R.; Hoffmann, M.; Hollinger, D.Y. Unique challenges and opportunities for northeastern US crop production in a changing climate. Clim. Chang. 2018, 146, 231-245. [CrossRef]

11. Chartzoulakis, K.; Bertaki, M. Sustainable water management in agriculture under climate change. Agric. Sci. Procedia 2015, 4, 88-98. [CrossRef]

12. Misra, A.K. Climate change and challenges of water and food security. Int. J. Sustain. Built Environ. 2014, 3, 153-165. [CrossRef]

13. Sweet, S.; Wolfe, D.W.; DeGaetano, A.T.; Benner, R. Anatomy of the 2016 drought in the Northeastern United States: Implications for agriculture and water resources in humid climates. Agric. For. Meteor. 2017, 247, 571-581. [CrossRef]

14. Gordon, L.J.; Finlayson, C.M.; Falkenmark, M. Managing water in agriculture for food production and other ecosystem services. Agric. Water Manag. 2010, 97, 512-519. [CrossRef]

15. Molden, D.; Oweis, T.; Steduto, P.; Bindraban, P.; Hanjra, M.A.; Kijne, J. Improving agricultural water productivity: Between optimism and caution. Agric. Water. Manag. 2010, 97, 528-535. [CrossRef]

16. Mo, X.G.; Hu, S.; Lin, Z.H.; Liu, S.X.; Xia, J. Impacts of climate change on agricultural water resources and adaptation on the North China Plain. Adv. Clim. Chang. Res. 2017, 8, 93-98. [CrossRef]

17. Rosenzweig, C.; Strzepek, K.M.; Major, D.C.; Iglesias, A.; Yates, D.N.; McCluskey, A.; Hillel, D. Water resources for agriculture in a changing climate: International case studies. Glob. Environ. Chang. 2004, 14, 345-360. [CrossRef]

18. Rasmussen, S.B.; Blenkinsop, S.; Burton, A.; Abrahamsen, P.; Holm, P.E.; Hansen, S. Climate change impacts on agro-climatic indices derived from downscaled weather generator scenarios for eastern Denmark. Eur. J. Agron. 2018, 101, 222-238. [CrossRef] 
19. Sojka, M.; Kozłowski, M.; Stasik, R.; Napierała, M.; Kęsicka, B.; Wróżyński, R.; Jaskuła, J.; Liberacki, D.; Bykowski, J. Sustainable water management in agriculture - the impact of drainage water management on groundwater table dynamics and subsurface outflow. Sustainability 2019, 11, 4201. [CrossRef]

20. Sojka, M.; Jaskuła, J.; Wicher-Dysarz, J. Assessment of biogenic compounds elution from the Główna River catchment in the years 1996-2009. Annu. Set Environ. Prot. 2016, 18, 815-830.

21. Dąbrowska, J.; Dąbek, P.; Lejcuś, I. Identifying surface runoff pathways for cost-effective mitigation of pollutant inputs to drinking water reservoir. Water 2018, 10, 1300. [CrossRef]

22. Mehdi, B.; Lehner, B.; Gombault, C.; Michaud, A.; Beaudin, I.; Sottile, M.F.; Blondlot, A. Simulated impacts of climate change and agricultural land use change on surface water quality with and without adaptation management strategies. Agric. Ecosyst. Environ. 2015, 213, 47-60. [CrossRef]

23. Sojka, M.; Murat-Błażejewska, S. Physico-chemical and hydromorphological state of a small lowland river. Annu. Set Environ. Prot. 2009, 11, 727-737.

24. Sojka, M. Assessment of biogenic compounds eluted from the catchment of Dębina River. Annu. Set Environ. Prot. 2009, 11, 1225-1234.

25. Lemke, A.M.; Kirkham, K.G.; Lindenbaum, T.T.; Herbert, M.E.; Tear, T.H.; Perry, W.L.; Herkert, J.R. Evaluating agricultural best management practices in tile-drained subwatersheds of the Mackinaw River, Illinois. J. Environ. Qual. 2011, 40, 1215-1228. [CrossRef]

26. Cooke, R.A.; Verma, S. Performance of drainage water management systems in Illinois, United States. J. Soil Water Conserv. 2012, 67, 453-464. [CrossRef]

27. Strock, J.S.; Kleinman, P.J.; King, K.W.; Delgado, J.A. Drainage water management for water quality protection. J. Soil Water Conserv. 2010, 65, 131-136. [CrossRef]

28. Jaynes, D.B.; Thorp, K.R.; James, D.E. Potential water quality impact of drainage water management in the Midwest USA. In Proceedings of the XVIIth World Congress of the International Commission of Agricultural Engineering, Québec City, QC, Canada, 13-17 June 2010. [CrossRef]

29. Skaggs, R.W.; Youssef, M.A.; Chescheir, G.M. DRAINMOD: Model use, calibration, and validation. Trans. ASABE 2012, 55, 1509-1522. [CrossRef]

30. Wang, Z.; Qi, Z.; Xue, L.; Bukovsky, M. RZWQM2 simulated management practices to mitigate climate change impacts on nitrogen losses and corn production. Environ. Modell. Softw. 2016, 84, 99-111. [CrossRef]

31. Ritzema, H.P.; Stuyt, L.C.P.M. Land drainage strategies to cope with climate change in the Netherlands. Acta Agric. Scand. B Soil Plant Sci. 2015, 65, 80-92. [CrossRef]

32. Skaggs, R.W.; Fausey, N.R.; Evans, R.O. Drainage water management. J. Soil Water Conserv. 2012, 67, 167-172. [CrossRef]

33. Iglesias, A.; Garrote, L. Adaptation strategies for agricultural water management under climate change in Europe. Agric. Water Manag. 2015, 155, 113-124. [CrossRef]

34. Malek, K.; Adam, J.C.; Stöckle, C.O.; Peters, R.T. Climate change reduces water availability for agriculture by decreasing non-evaporative irrigation losses. J. Hydrol. 2018, 561, 444-460. [CrossRef]

35. Falloon, P.; Betts, R. Climate impacts on European agriculture and water management in the context of adaptation and mitigation-the importance of an integrated approach. Sci. Total Environ. 2010, 408, 5667-5687. [CrossRef] [PubMed]

36. Connor, J.D.; Schwabe, K.; King, D.; Knapp, K. Irrigated agriculture and climate change: The influence of water supply variability and salinity on adaptation. Ecol. Econ. 2012, 77, 149-157. [CrossRef]

37. Hack-ten Broeke, M.J.D.; Mulder, H.M.; Bartholomeus, R.P.; van Dam, J.C.; Holshof, G.; Hoving, I.E.; Walvoort, D.J.J.; Heinen, M.; Kroes, J.G.; van Bakel, P.J.T.; et al. Quantitative land evaluation implemented in Dutch water management. Geoderma 2019, 338, 536-545. [CrossRef]

38. Huang, S.; Wortmann, M.; Duethmann, D.; Menz, C.; Shi, F.; Zhao, C.; Su, B.; Krysanova, V. Adaptation strategies of agriculture and water management to climate change in the Upper Tarim River basin, NW China. Agric. Water Manag. 2018, 203, 207-224. [CrossRef]

39. Harrison, M.T.; Cullen, B.R.; Rawnsley, R.P. Modelling the sensitivity of agricultural systems to climate change and extreme climatic events. Agric. Syst. 2016, 148, 135-148. [CrossRef]

40. Øygarden, L.; Deelstra, J.; Lagzdins, A.; Bechmann, M.; Greipsland, I.; Kyllmar, K.; Povilaitis, A.; Iital, A. Climate change and the potential effects on runoff and nitrogen losses in the Nordic-Baltic region. Agric. Ecosyst. Environ. 2014, 198, 114-126. [CrossRef] 
41. Golmohammadi, G.; Rudra, R.P.; Prasher, S.O.; Madani, A.; Goel, P.K.; Mohammadi, K. Modeling the impacts of tillage practices on water table depth, drain outflow and nitrogen losses using DRAINMOD. Comput. Electron. Agric. 2016, 124, 73-83. [CrossRef]

42. Sun, S.K.; Li, C.; Wu, P.T.; Zhao, X.N.; Wang, Y.B. Evaluation of agricultural water demand under future climate change scenarios in the Loess Plateau of Northern Shaanxi, China. Ecol. Indic. 2018, 84, 811-819. [CrossRef]

43. Łabędzki, L. Parameterization of drought vulnerability assessment in agriculture. Infrastruct. Ecol. Rural Areas 2017, 2, 535-544. [CrossRef]

44. Iuss Working Group Wrb. World Reference Base for Soil Resources 2014, Update 2015: International Soil Classification System for Naming Soils and Creating Legends for Soil maps. World Soil Resources Reports; FAO: Rome, Italy, 2015.

45. Skaggs, R.W. A Water management Model for Shallow Water Table Soils; Water Resources Research Institute of the University of North Carolina: Raleigh, NC, USA, 1978.

46. Youssef, M.A.; Abdelbaki, A.M.; Negm, L.M.; Skaggs, R.W.; Thorp, K.R.; Jaynes, D.B. DRAINMOD-simulated performance of controlled drainage across the US Midwest. Agric. Water Manag. 2018, 197, 54-66. [CrossRef]

47. Fouss, J.L.; Bengtson, R.L.; Carter, C.E. Simulating subsurface drainage in the lower Mississippi Valley with DRAINMOD. Trans. ASAE 1987, 30, 1679-1688. [CrossRef]

48. Dayyani, S.; Madramootoo, C.A.; Enright, P.; Simard, G.; Gullamudi, A.; Prasher, S.O.; Madani, A. Field evaluation of DRAINMOD 5.1 under a cold climate: Simulation of daily midspan water table depths and drain outflows. Jour. Amer. Wat. Res. Assoc. 2009, 45, 779-792. [CrossRef]

49. Willmott, C.J. On the validation of models. Phys. Geogr. 1981, 2, 184-194. [CrossRef]

50. Loague, K.; Green, R.E. Statistical and graphical methods for evaluating solute transport models: Overview and application. J. Contam. Hydrol. 1991, 7, 51-73. [CrossRef]

51. Mezghani, A.; Dobler, A.; Haugen, J.E. CHASEPL Climate Projections: 5-km Gridded Daily Precipitation $\mathcal{E}$ Temperature Dataset (CPLCP-GDPT5); Norwegian Meteor. Inst.: Oslo, Norway, 2016.

52. Piniewski, M.; Mezghani, A.; Szcześniak, M.; Kundzewicz, Z.W. Regional projections of temperature and precipitation changes: Robustness and uncertainty aspects. Meteorol. Z. 2017, 26, 223-234. [CrossRef]

53. Kundzewicz, Z.W.; Piniewski, M.; Mezghani, A.; Okruszko, T.; Pińskwar, I.; Kardel, I.; Hov, Ø.; Szcześniak, M.; Szwed, M.; Benestad, R.E.; et al. Assessment of climate change and associated impact on selected sectors in Poland. Acta Geophys. 2018, 66, 1509-1523. [CrossRef]

54. Pease, L.A.; Fausey, N.R.; Martin, J.F.; Brown, L.C. Projected climate change effects on subsurface drainage and the performance of controlled drainage in the Western Lake Erie Basin. J. Soil Water Conserv. 2017, 72, 240-250. [CrossRef]

55. Tan, C.S.; Drury, C.F.; Gaynor, J.D.; Welacky, T.W.; Reynolds, W.D. Effect of tillage and water table control on evapotranspiration, surface runoff, tile drainage and soil water content under maize on a clay loam soil. Agric. Water Manag. 2002, 54, 173-188. [CrossRef]

56. Wang, Z.; Qi, Z.; Xue, L.; Bukovsky, M.; Helmers, M.J. Modeling the impacts of climate change on nitrogen losses and crop yield in a subsurface drained field. Clim. Chang. 2015, 129, 323-335. [CrossRef]

57. Gilliam, J.W.; Skaggs, R.W. Controlled agricultural drainage to maintain water quality. J. Irrig. Drain. Eng. 1986, 112, 254-263. [CrossRef]

58. Wesström, I.; Messing, I.; Linner, H.; Lindström, J. Controlled drainage-effects on drain outflow and water quality. Agric. Water Manag. 2001, 47, 85-100. [CrossRef]

59. Sunohara, M.D.; Gottschall, N.; Craiovan, E.; Wilkes, G.; Topp, E.; Frey, S.K.; Lapen, D.R. Controlling tile drainage during the growing season in Eastern Canada to reduce nitrogen, phosphorus, and bacteria loading to surface water. Agric. Water Manag. 2016, 178, 159-170. [CrossRef]

60. Sunohara, M.D.; Gottschall, N.; Wilkes, G.; Craiovan, E.; Topp, E.; Que, Z.; Seidou, O.; Frey, S.K.; Lapen, D.R. Long-term observations of nitrogen and phosphorus export in paired-agricultural watersheds under controlled and conventional tile drainage. J. Environ. Qual. 2015, 44, 1589-1604. [CrossRef] [PubMed]

61. Baule, W.; Allred, B.; Frankenberger, J.; Gamble, D.; Andresen, J.; Gunn, K.M.; Brown, L. Northwest Ohio crop yield benefits of water capture and subirrigation based on future climate change projections. Agric. Water Manag. 2017, 189, 87-97. [CrossRef]

62. Bonaiti, G.; Borin, M. Efficiency of controlled drainage and subirrigation in reducing nitrogen losses from agricultural fields. Agric. Water Manag. 2010, 98, 343-352. [CrossRef] 
63. Lal, R.; Delgado, J.A.; Groffman, P.M.; Millar, N.; Dell, C.; Rotz, A. Management to mitigate and adapt to climate change. J. Soil Water Conserv. 2011, 66, 276-285. [CrossRef]

64. Negm, L.M.; Youssef, M.A.; Jaynes, D.B. Evaluation of DRAINMOD-DSSAT simulated effects of controlled drainage on crop yield, water balance, and water quality for a corn-soybean cropping system in central Iowa. Agric. Water Manag. 2017, 187, 57-68. [CrossRef]

65. Dayyani, S.; Prasher, S.; Madani, A.; Madramootoo, C. Impact of Climate Change on Drainage Outflow and Water Quality in Eastern Canada. In Proceedings of the 9th Int. Drain. Symp. held jointly with CIGR and CSBE/SCGAB, Québec City Conv. Centre, Quebec City, QC, Canada, 13-16 June 2010; American Society of Agricultural and Biological Engineers: St. Joseph, MI, USA, 2010; pp. 1-12.

66. Golmohammadi, G.; Rudra, R.; Prasher, S.; Madani, A.; Mohammadi, K.; Goel, P.; Daggupatti, P. Water budget in a tile drained watershed under future climate change using SWATDRAIN model. Climate 2017, 5, 39. [CrossRef]

67. Mehan, S.; Aggarwal, R.; Gitau, M.W.; Flanagan, D.C.; Wallace, C.W.; Frankenberger, J.R. Assessment of hydrology and nutrient losses in a changing climate in a subsurface-drained watershed. Sci. Total Environ. 2019, 688, 1236-1251. [CrossRef] [PubMed]

68. Duffková, R.; Fučík, P.; Jurkovská, L.; Janoušková, M. Experimental evaluation of the potential of arbuscular mycorrhiza to modify nutrient leaching in three arable soils located on one slope. Appl. Soil Ecol. 2019, 143, 116-125. [CrossRef]

69. Duffková, R.; Holub, J.; Fučík, P.; Rožnovský, J.; Novotný, I. Long-Term water balance of selected field crops in different agricultural regions of the Czech Republic using fao-56 and soil hydrological approaches. Sustainability 2019, 11, 5243. [CrossRef]

70. Cogato, A.; Meggio, F.; De Antoni Migliorati, M.; Marinello, F. Extreme weather events in agriculture: A systematic review. Sustainability 2019, 11, 2547. [CrossRef]

71. Hunink, J.; Simons, G.; Suárez-Almiñana, S.; Solera, A.; Andreu, J.; Giuliani, M.; Zamberletti, P.; Grillakis, M.; Koutroulis, A.; Tsanis, I.; et al. A simplified water accounting procedure to assess climate change impact on water resources for agriculture across different European river basins. Water 2019, 11, 1976. [CrossRef]

72. Van den Eertwegh, G.A.P.H.; van Bakel, P.J.T.; Stuyt, L.; van Iersel, A.; Kuipers, L.; Talsma, M.; Droogers, P. Climate Adaptive Drainage: An Innovative Method to Reduce Peak Discharges and Water Shortages-Summary and Conclusions Phase 2. Future Water Rapport 123; Wageningen, The Netherlands, 2013. 